\title{
A NAGYVÁROSI KORMÁNYZATOK ÉS AZ ÖNKORMÁNYZATI RENDSZER ${ }^{1}$
}

\author{
(Governments of the Cities and System of the Local
}

\author{
Government)
}

\section{HEGEDÜS JÓZSEF}

Kulcsszavak:

önkormányzat nagyvárosok kormányzati struktúrák helyi hatalom

A tanulmány a városi kormányzatokkal kapcsolatos nemzetközi irodalom rövid áttekintése után a magyar nagyvárosok helyzetét tárgyalja két összefüggésben: egyrészt az önkormányzati rendszeren, másrészt pedig az állam és a magánszektor kapcsolatrendszerén keresztül. A dolgozat arra a következtetésre jut, hogy a nagyvárosok a magyar önkormányzati rendszeren belül egyfajta speciális érdekcsoportot jelentenek, amelyek egyrészt meghatározó politikai súllyal rendelkeznek a terilleti folyamatokban és a központi költségvetési politikában, másrészt pedig adottságaik révén a gazdasági fejlödés „,növekedési pólusait" képviselik.

A politikai rendszerváltás társadalmi következményei két átfogóbb folyamatra vezethetook vissza: a privatizációra és a decentralizációra. A társadalomkutatók és a politikusok között máig vitatott kérdés, hogy a privatizáció és a decentralizáció hogyan járult hozzá az ország gazdasági-politikai átalakulásához. Bár sok minden eldőlt, mindkét területen vannak nyitott kérdések. A parlamentben és a parlamenten kivül ma is viták vannak a privatizáció további menetéröl, az állami tulajdon kívánatos mértékéról. Az 1990-es radikális decentralizáció értékelésében sincs egyetértés; míg sokáig Magyarország a térség minta-országa volt, ma már sokan kétségbe vonják a közigazgatási reformok hatékonyságát, és újabb radikális átalakulást sürgetnek. ${ }^{2}$ De nemcsak a politikusok nem tudtak dúlöre jutni stratégiai kérdésekben, a társadalomtudomány sem lehet elégedett a folyamatok elemzésével és értékelésével.

Ez az írás a decentralizáció következményeivel foglalkozik, azon belül is egy komplex kérdéskörrel: a városi kormányzatok müködésének új feltételeivel. Az elemzés elsösorban az állami közfeladatok megosztására és a finanszírozási feltételek változására koncentrál, és ezek alapján kísérel meg hipotéziseket felállitani a városok szerepével és lehetőségeivel kapcsolatban.

A tanulmány a magyarországi nagyvárosok (melyeket lényegében a megyei jogú városokkal azonosíthatunk) helyzetére koncentrál. A megyei jogú városok a magyar településrendszerben egy speciális „települési osztályt” képviselnek, és amelyek az egyetlen magyar világváros, Budapest és a kisvárosok között helyezkednek el. A megyei jogú városok a magyar városi struktúra második szintjét képviselik, messze elmaradva az egyedüli nagyvárostól (Budapesttől), amely az egyedüli olyan városi térség, amely megfelel az ESPON kutatás nagyvárosi kritériumainak (legalább 500 ezer lakos él egy összefüggó munkaerö-piaci térségben stb.). A magyar- 
országi nagyvárosok tehát nagyságrendileg kisebbek, mint az európai nagyvárosok, lényegében az európai harmadik városszintnek felelnek meg. Az állandó lakosság alapján számolva a népesség egyötödét képviselik, és a vonzáskörzetïkben lévő közel 450 településen élö további több mint egy millió fővel együtt az ország lakosságának 30\%-a él az így definiált nagyvárosi környezetben. Érdekes, hogy a városokkal foglalkozó kutatások viszonylag elhanyagolták ezt a területet, a kutatók sokkal nagyobb érdeklődést tanúsítottak a nagyvárosok kialakulása és növekedése, és a globalizált világban betöltött szerepváltozása iránt (Markusen et al 1999).

Kutatásaink során egyre gyakrabban szembesültünk azzal, hogy Budapest és a megyei jogú városok (vagy a hozzájuk hasonló még 10-20 középváros) kitüntetett szerepet játszanak központi programokban, választott vezetöik (polgármesterek) meghatározó szereplői a pártoknak, és sokan képviselőként is fontos pozíciót foglalnak el a parlamentben. Ezek a városok dominálják a környezetükben lévő településeket, azok fejlettsége a központi várostól függ. Továbbá a magánszektor által meghatározott gazdasági fejlesztések is (bevásárlóközpontok, pénzügyi intézetek, egészségügyi intézmények, felsőoktatás, közlekedés stb.) jelentős mértékben a fővároshoz, a megyei városokhoz és azok környékéhez kötődnek. Természetesen Budapestre ez fokozottabban érvényes, hiszen a föváros kiemelt politikai, gazdasági és kulturális szerepe miatt közvetlen meghatározója a területi folyamatoknak, és gazdálkodásában a normatív elemeket (támogatások, helyi bevételek stb.) háttérbe szorítják az egyedi politikai alkuk (metrófinanszírozás, BKV stb.)

Talán úgy fogalmazhatunk, hogy a területfejlesztés meghatározó szereplöi a megyei városok, amelyek aktívan befolyásolják, módosítják az ágazati programokat, közigazgatási koncepciókat stb. Ugyanakkor a városok között is komoly verseny van az erőforrásokért, és a verseny kimenetele a gazdasági adottságokon kívül a helyi politikai vezetés hozzáértésétől, kapcsolatrendszerétől függ.

Ebben a dolgozatban rövid nemzetközi és elméleti kitekintés után megkísérlünk megfogalmazni néhány hipotézist a magyar nagyvárosi kormányzatokkal kapcsolatban.

\section{A nagyvárosi kormányzatok - globalizáció, decentralizáció és szomszédsági területek}

A városfejlődés nemzetközi trendjét az 1980-as évektől kezdve egyre inkább a globalizációs folyamatok határozzák meg, melyek következtében a városi hálózatok átalakultak, a közvetlen földrajzi környezet szerepe (város és környék kapcsolatának) hatása mérséklödött, és a siker zálogává egyre inkább a nemzetközi munkamegosztásban való sikeres részvétel vált. A globalizáció jelei (multinacionális nagyvállalatok és pénzintézetek megjelenése, a nemzetközi munkamegosztás, a migráció és a turizmus jelentőségének növekedése és ezek hatása a kulturális tényezőkre stb.) érzékelhetőek a poszt-szocialista városfejlődésben (Szirmai 2004). Ugyanakkor a globalizáció valódi gazdasági és politikai jelentősége eltúlzott, a kutatások még nem 
igazolták, hogy a városfejlődésben ezek a folyamatok meghatározó szerepet játszanának, különösen a Budapesten kívüli városi térségek folyamataiban.

A magyar városok helyzetének elemzését segitheti a nemzetközi irodalom következő két, egymással sokszor csak érintőlegesen kapcsolódó területének az áttekintése. Az egyik a decentralizáció, a kormányzat különbözó szintjei közötti kapcsolatok rendszerének változása, amely végső soron azzal az alapvető kérdéssel foglalkozik, hogy a városok mekkora autonómiával rendelkeznek a helyi gazdaság és társadalom alakításában. A másik terület pedig a helyi kormányzati rendszerek struktúrájának változása, melynek legalább két fontos dimenzióját kell megkülönböztetni: 1) a városi térség, a város és a városon belüli közigazgatási egységek közötti kapcsolatokat; valamint 2) a közszektor és magánszektor közötti kapcsolatok változását.

Érdekes, hogy mindkét területnek könyvtárnyi irodalma van, de nem könnyü olyan elemzést találni, amely a két területet (a decentralizációt és a kormányzati rendszereket) egymással való összefüggésében elemezné. Tudjuk, hogy az európai nagyvárosok sokkal nagyobb mértékben függnek a központi kormányzatoktól, mint az észak-amerikaiak, de a konkrét összehasonlító munkákból nagyon nehezen ítélhető meg egy-egy nagyváros valódi autonómiája. Az irodalomból az is kiolvasható, hogy a globalizáció együtt járt egyfajta decentralizációval és a kormányzati struktúra változásával, de még az empirikus munkák szerzöi is óvatosak abban, hogy a kialakult komplexebb rendszerekböl általános következtetéseket vonjanak le (pl. Lefevre 2001).

Mielőtt tehát a magyar önkormányzati rendszer és a városok közötti kapcsolat elemzésére térnénk, érdemes röviden áttekinteni, hogy a fejlettebb társadalmakban (elsősorban az európai országokban) milyen trendek érvényesültek a decentralizáció és a városi kormányzatok területén.

\section{A nagyvárosi kormányzat helye a területi rendszeren belül}

Az európai országok nagyon eltérö képet mutatnak az önkormányzati rendszerek struktúrája tekintetében. A föderatív berendezkedésủ országokban az egyes tartományok, szövetségi államok automatikusan régiót alkotnak, amelyek tipikusan rendelkeznek saját választott parlamenttel, kormánnyal, törvényhozással és van önálló adózási joguk (Németország, Ausztria, Belgium és a nem EU-tag Svájc). A másik típust az alkotmány által garantált régiókkal rendelkezỏ országok képviselik, mint pl. Spanyolország (1978). A régiókra épülö területi igazgatás viszonylag új, sokszor vitatott rendszer. Nagy-Britanniában és Olaszországban csak az 1990-es években indult meg ez a folyamat, és ma is tart. A harmadik típusba a decentralizált országok tartoznak, ahol az alkotmányos jogokkal nem rendelkezö regionális szervezetek csak korlátozott hatáskörrel rendelkeznek (pl. Hollandia, Dánia, Svédország). Végül az utolsó csoportba az unitárius önkormányzati rendszerekkel rendelkező országok sorolódnak, ahol a régió politikai autonómia nélküli kormányzati szint, pl. Portugália, Görögország, Írország, Luxemburg. 
A 2004-es csatlakozás elötti európai országok esetében nehéz lenne az önkormányzati rendszer széttagoltsága és a politikai berendezkedés alapján következtetést levonni a nagyvárosok fiskális, pénzügyi önállóságára nézve. A önkormányzatok súlya a GDP-n belül és a települések bevételi és kiadási szerkezete önmagában csak nagyon korlátozott mértékben enged következtetni a városok pénzügyi autonómiájára.

Hasonlóképpen nem könnyú átfogó európai trendekre következtetni az önkormányzatok mérete alapján. A nyugat-európai önkormányzati rendszerek az elmúlt 50 évben jelentős változásokon mentek keresztül, de a történeti elemek máig meghatározó különbségeket jelentenek. Az1960-as és 1970-es években az önkormányzati rendszerek konszolidációs-integrációs hulláma söpört végig Európán (Anglia, Svédország, Dánia, Nyugat-Németország), nem érintve azonban olyan fontosabb országokat, mint Franciaország, Olaszország és Spanyolország. Ezt a politikát nagyban segítette az „optimális településnagyság” elmélete, amely a közszolgáltatások gazdasági hatékonyságának növelése érdekében a nagyobb településnagyság mellett tette le a voksot (Singell 1974; Arnott 1979). Érdekes módon a 1970-es években a kelet-európai szocialista országok településpolitikájára is hatott ez az elmélet. Ennek puhább változata volt hazánkban az 1970-es években kidolgozott településfejlesztési koncepció és az azt követő település-összevonási hullám. Jóval durvább változatot képviselt a romániai „szisztematizáció”, az a településfejlesztési gyakorlat, amely kisebb települések elsorvasztását, felszámolását eredményezte a fejlesztések nagyvárosokra való koncentrálása érdekében. Az európai országokban az önkormányzatok átlagos településnagysága 100-szoros különbséget tartalmazó skálán mozog, melynek az egyik szélén Franciaország (1,5 ezer fö), a másikon pedig Skócia (156 ezer fó) helyezkedik el. Következésképpen az önkormányzatok nagyság szerinti összetétele nem csak nagyban különbözik egymástól, de még csak hasonló trendeket sem találhatunk.

Talán a leginkább érzékelhető átfogó trend a regionalizmus erősödése, bár ez közel sem egyirányú folyamat, mivel a centralista (központi kormányzatot erősítő) és a decentralista (régiók alatti) területek befolyása idóröl-idöre újra előkerül. Tény azonban, hogy a nemzetállamok, amelyek történetileg fontos szerepet játszottak a városi autonómiák 19. század második felében tỏrténő felszámolásában, az unitariánus, centralizált kormányzati berendezkedés kialakításában, az EU nyomása alatt, a decentralizációs politika felé mozdultak el. Ennek legfontosabb eleme az Ebizottság által is támogatott régiók voltak. Az EU a hetvenes évek közepétől kezdve (ERDF - European Regional Development Fund felállíása után) törekedett az európai regionalizáció elősegitésére (azaz nemzetállamok alatti, relatív önálló kormányzati szint kialakítására). A „régiók Európája” koncepció mögött részben a területi különbségek mérséklését célul kitüző közösségi politika húzódott meg, részben pedig az a törekvés, hogy csökkenjenek a nemzetállamok közötti rivalizálás okozta zavarok. A regionális különbségek kezelése Görögország (1981) és Portugália, Spanyolország (1986) csatlakozása után vált különösen fontossá, amikor az Európai Unió területe 32\%-kal, népessége 18\%-kal, de GDP-je csupán 13\%-kal lett 
nagyobb. Az elmaradt térségek felzárkóztatását elősegítő programok igazolták, hogy az EU-tagok hajlandóak a GDP egy részének újraelosztására.

$\mathrm{A} z$ Unió által támogatott regionalizáció mellett számos európai országban jelenlévő törekvés az alulról építkező regionalizmus, amely történeti, etnikai, kulturális alapon igyekszik területi politikai önállóság megszerzésére. A folyamat eredménye a politikai és gazdasági önállósággal rendelkező régiók kialakulása, sokszor önálló állam létrehozásának szándékával. Ez a törekvés nemcsak a nemzeti kormányzatok, de az EU bürokrácia ellenállásába is ütközik, pl. a baszkok, katalánok követelései $\mathrm{ma}$ is a politikai konfliktusok jelenlévő eleme.

Lefevre (2001) szerint a regionalizálás egyértelmủ vesztesei a nagyvárosok voltak, amelyek nem voltak képesek a nemzetállamok és a települések közötti politikai/hatalmi ürbe benyomuló régiókat visszaszorítani. Ennek ellenére a nagyvárosok hatalmi törekvései nem csillapodtak, és időről-időre előjönnek olyan javaslatok, amelyek a nagyvárosoknak a térségszervezés területén nagyobb súlyt kívánnak biztosítani. A város-régió koncepció jó példa erre.

Az európai településrendszer a policentrikus struktúra felé mozdult el, ami elsösorban az urbanizált térségekben meglévő kiegyenlített hatalmi viszonyok következtében alakult így, és ezt a trendet az uniós szinten megfogalmazott politikák is erősítik.

\section{A nagyvárosi kormányzatok: egyszintü, kétszintü és a policentrikus struktúrák}

Az elmúlt fél évszázadban a városok kormányzási környezete lényeges átalakuláson ment keresztül (Vogel 2005). Az urbanizáció tovább folytatódott, a nagyvárosok és környékük lakosságszáma tovább növekedett. A városi térségek növekedése, különösen a decentralizált közigazgatási és önkormányzati rendszerekben, élesebben felvetette a városi övezetek önkormányzatai közötti együttmüködés problémáit. A kormányzati széttagoltság elsősorban a közszolgáltatások hatékony biztosítása terén okozott problémákat. További konfliktusok forrásává váltak a területi különbségek (szolgáltatások eltérő színvonala) és az egymás közelségében elhelyezkedő önálló önkormányzatokkal rendelkező települések anyagi helyzete (adókapacitás) közötti különbségek.

Ezek a problémák már a múlt század elején felvetődtek, amikor a tipikus megoldás a nagyvárosok környéki települések beolvasztása (egyesítése) volt, amit jól illusztrálnak a London, Bécs és Berlin esetében megvalósított beolvasztások. A városok és a környezö települések összeolvasztása a múlt század közepétöl azonban már komoly politikai ellenállásba ütközött. A nagyvárosok kormányzataival foglalkozó kutatók álláspontja is megoszlott. Az egységes nagyváros elönyei mellett érveló álláspont ((Jones 1942; Gulick 1957) mellett egyre meghatározóbb lett a „public choice” elméletre épülö, kisebb területi egységek létezését igenlö álláspont, (Ostrom-Tiebout-Warren 1961; Bish-Ostrom 1973). Különösen a leggyorsabban 
urbanizálódó észak-amerikai kontinensen (Kanada és az Egyesült Államok) váltott ki nagy vitát, hogy mi az optimális megoldás.

A városi kormányzati struktúrát három alaptípusba sorolja az irodalom (Barlow 1997; 2000; Bird-Slack 2004). Az egyszintü kormányzat a város és környéke településeinek összevonásával jön létre, ahol a város egészét képviselő választott testületek rendelkeznek a szükséges kompetenciával. A tipikus érv az összevonás mellett a nagyvárosok versenyképességének növelése és a nagyváros belső tagoltságával, különbségeivel járó konfliktusok csökkentése. Bár a politikai ellenállás és a decentralizáció melletti praktikus érvek a kilencvenes években általában nem kedveztek ennek a megoldásnak, több város alkalmazta Kanadában (Halifax 1996; Toronto 1998; Montreál 2002). Sokszor azonban a politikai ellenállás megakadályozta az összevonást (pl. Helsinki, vagy Hollandia). A kétszintü városi kormányzati rendszer a kormányzati feladatokat megosztja egyrészt (a) a nagyvárosi terület egészét képviselö (választott) testület, és (b) az egyes városrészeket (kerületeket) képviselö testületek között, ahol a feladatok és a bevételek megoszlanak. A kétszintü kormányzat egyik első változatát képviseli London már a 19. század végén, de a kétszintü nagyvárosi kormányzati modellek a hatvanas és hetvenes években válnak népszerüvé: Angliában a nyolcvanas évek elejére a népesség több mint fele él valamilyen kétszintủ nagyvárosi önkormányzat területén. A kétszintủ kormányzat létrejöttét általában megelózik az egyes funkciókra szerveződő kooperációk (tervezés, víz és csatorna, rendőrség). Például a vancouveri kétszintủ önkormányzat létrejötte előtt régen megvoltak a koordinativ szervezetek a legfontosabb regionális funkciókra (a víz- és szennyvízkezelés és tervezés). A policentrikus kormányzati struktúrák jellemzöje, hogy egy önkormányzati szint van, és a térségi feladatokat ad hoc testületek révén, önkormányzatok közötti kooperatív megállapodásokon keresztül oldják meg (Barlow 2000). Ebben a modellben több központi település is elképzelhetö, de tipikus esetben felállítják a nagyvárosi önkormányzatok tanácsát. Az Egyesült Államokban jellemző ez a modell, ahol az önkormányzatok politikailag elég erősek voltak ahhoz, hogy megakadályozzák a kétszintủ kormányzatok kialakulását, de ma már sokan amellett érvelnek, hogy a kormányzati struktúrák sokkal kevésbé fontosak, mint a tényleges, gyakran nem formalizált ágazati és területi kooperációk.

A funkcionálisan összetartozó városi területnek (FUA: functional urban area) megfelelö igazgatási rendszerek nem könnyen alakíthatók ki. Ennek oka nemcsak a kisebb települések ismert politikai ellenállása, hanem az is, hogy a FUA nem határozható meg könnyen, mivel az egyes szektorok (egészségügy, közlekedés, rekreáció stb.) más és más vonzáskörzetekkel rendelkeznek, továbbá időben (technológia, urbanizáció stb.) ezek a vonzásterületek is változnak.

Kanadában a nagyvárosi kormányzati struktúrát a tartományi szint döntése határozza meg. A hosszú ideig példaképnek számító torontói kétszintú kormányzatot (metropolitan government) a tartomány döntése alapján számolták fel, és helyettesítették egy lényegében egyszintủ struktúrával. A városok központi költségvetésböl származó forrásaikat a tartományok közvetítésével kapják meg, és újdonságnak számítanak azok a programok, amelyek a szövetségi kormány adóbevételeiböl köz- 
vetlenül a városoknak juttatnak támogatásokat (2004 után az üzemanyagadó bevétel felét tervezték például városi programokra felhasználni. A középszint (régió, tartomány vagy megye) szerepe meghatározó szerepet játszik a városi kormányzatok átalakulásában. Az Egyesült Államokban viszonylag ritka a magyarországihoz hasonló helyzet, amikor a kormányzati rendszer középső szintjéből (county) kiemelik a városokat, ezen, ún. független városok (48) többsége Virginiában található. A kormányzat korszerüsítésének egyik módja a városok és a megyék integrációja, a két elkülönülő szint felszámolása.

Sok városban nincs megoldva a nagyváros és a vele funkcionálisan egybetartozó városkörnyék egységes közigazgatása, és ezt a problémát az önkéntes alapon szervezett kooperációk nem tudják ellensúlyozni. Nagy-Britanniában a hatvanas évek sikertelen kísérletei után napjainkban került megint elötérbe a városkörnyéki közigazgatási rendszerek kialakításának gondolata. Az ez irányú törekvések politikai támogatottsága azonban meglehetősen kicsi, azt is mondhatnánk, hogy szinte kizárólag a miniszterelnök-helyettesi iroda (Office of the Deputy Prime Minister) szándékait tükrözi. Az ellenállást leginkább az indokolja, hogy az elmúlt években oly nehezen kialakult regionális intézményrendszer megerösödött. Az újonnan létrejött intézmények - pl. regionális ügynökségek - pedig meg akarják szilárdítani pozícióikat, amelyeket az új városrégiók erősen veszélyeztetnének.

\section{Városon belüli térségek: kerületek és szomszédsági körzetek}

A nagyvárosok és környékük településeinek összeolvadása nagyon nagyméretủ városokat eredményezett, amelyeken belül a közigazgatási funkciók hatékony ellátása érdekében kisebb egységeket (kerületeket) hoztak létre. Ezek az egységek tipikusan a nagyvárosok dekoncentrált egységei („elöljáróságok”) voltak, de a nyolcvanas és kilencvenes években a közigazgatási rendszerekkel foglalkozó szakirodalom új irányzata (public choice elmélet) a városon belüli körzetek (szomszédságok) önállóságának előnyei mellett érvelt. A kerületi közigazgatási egységek kialakítása és önállóságának növelése mögött a decentralizáció ismert elönyein és hátrányain kívül a közvetlen lakossági részvétel szerepének növelése is szerepet játszott. A nyolcvanas és kilencvenes években számos nagyváros kísérletezett a helyi érdekek szisztematikus bekapcsolásával a döntési folyamatokba. Ezeknek a törekvéseknek nagy lökést adott Európában az, hogy a városrehabilitációs programok hatékonysága jelentős mértékben függ a lakossági részvételtöl, melynek intézményes megoldása valamiféle kerületi-szomszédsági képviselet. De számos más tényező (helyi szolgáltatások, szolidaritás, politikai részvétel) is a kisebb területi egységek növekvő kormányzati szerepét erősíti, egyfajta „új lokalitás" van kialakulóban, (Atkinson 2004; Lowndes-Sullivan 2006).

A kerületek vagy szomszédságok jogi státusza általában a városi közgyứlés/parlament által elfogadott (néha a parlament által is kodifikált) rendszertöl függött. Ritka az a megoldás, hogy a kerületek önkormányzati jogokkal rendelkezze- 
nek, amit pl. Budapest esetében választott a parlament 1990-ben. (Budapest kormányzati struktúrája a nagyvárosi kétszintủ önkormányzathoz áll közel, inkább a magyar részönkormányzatok felelnek meg az így definiált kerületeknek.) A nagyvároson belüli kerületek feladatai és a feladatok finanszírozása tipikus esetben a nagyváros törvényhozásától függ. Amszterdam az 1980-as években decentralizálta a városigazgatást, és kialakított 16 kerületet. Kezdetben csak három, majd a kilencvenes évektől kezdve mindegyik kerületben választott tanács müködött, kivéve a központi városrészeket és a kikötői részt, amely központi irányítás alatt maradt. A kerületek fontos szerepet játszanak a tervezésben, az épitési engedélyezésben, és jelentős forrásokat kapnak a várostól. Barcelonában 1979-ben hoztak létre 10 kerületet átlagosan 200 ezer lakossal(!), amelynek a célja egy decentralizáltabb modell bevezetése volt. A költségvetés $12 \%$-a felett rendelkeznek a kerületek. A kerületekben, hasonlóan a budapesti rendszerhez, képviselőtestületet és közvetlenül polgármestert választanak, ami azt jelenti, hogy a testületben nem a polgármester mögött álló párt van többségben. A kerületi határok nagyrészt a 18. és 19. században annektált települések határainak felelnek meg. A kerületeknek feladata van a városfejlesztés, az utak fenntartása és egyéb szolgáltatások területén. Más típust képviselnek az alulról jövő kezdeményezések, amelyek egy-egy kisebb közösségnek a kormányzatban való aktívabb részvételre való törekvéseit képviselik, mint például a Los Angeles-en belüli szomszédsági szervezetek (Box-Musso 2004). Kérdéses, hogy egy helyi szerveződésü „nonprofit" szervezet milyen feltételek mellett válhat az adott terület egészét és nem csak egy kisebb, aktív csoportot képviselő szervezetté.

A kelet-európai nagyvárosok a politikai rendszer bukása után fontos döntés elé állították a törvényhozókat. A korábbi centralizált-hierarchikus közigazgatási rendszerekben a városi szint alatt mindenhol megtalálhatók voltak a kerületek, sőt, sokszor még az ez alatti szint, a szomszédsági körzetek (mikrorayon) is. Ezek az egységek tipikusan a városi szintü közigazgatás dekoncentrált szervei voltak, többkevesebb igazgatási önállósággal. Tipikus esetben kerületi vállalatok gondoskodtak az állami bérlakások és a közintézmények épületállományának fenntartásáról, a kerületi hivatalokban adtak helyet az adóhivatal kihelyezett részlegeinek stb. Ezek az egységek, még ha választott testületekkel rendelkeztek is, nem hoztak önállóan döntéseket, valamennyi kérdésben a felsőbb közigazgatási (vagy helyesebben pártigazgatási) szint jóváhagyására, legitimációjára volt szükség. A rendszerváltást követö reformok során nyitott kérdés volt, hogy mi legyen a funkciója a kerületi szintnek, amivel kapcsolatban sem a szakirodalom, sem a nyugat-európai/északeurópai tapasztalatok nem adtak világos útmutatảst. A nagyvárosok belső struktúrájának kérdése tehát akkor vetődött fel igazán, amikor a decentralizációs folyamat következtében a nagyvárosok valódi döntési kompetenciákat kaptak (pl. Macedóniában 2000 után, Szerbiában 2004 után); ekkor már komoly politikai döntéssé vált, hogy a kompetenciákat és felelősségeket hogyan osztják el. 
Hegedüs József : A nagyvárosi kormányzatok és az önkormányzati rendszer.

Tér és Társadalom 22. évf. 2008/1. 59-75. p.

TÉT XXII. évf. 2008

A nagyvárosi kormányzatok ...

67

\section{Az irányítảsi rendszer átalakulása: érdekeltek bevonása a kormányzásba}

Az 1980-as és 1990-es évek nagy elmozdulása a nagyvárosi kormányzati struktúrákban a magánszektor és az érdekeltek bevonása az irányításba, ami összekapcsolódott a hagyományos keynes-i gazdaságpolitikára épülö állami beavatkozás leépülésével, a központi állam decentralizációjával, az állami tulajdon részleges privatizációjával, valamint a magánszektornak a kormányzati feladatok végrehajtásában való szorosabb bekapcsolásával. A nyolcvanas évektől kezdődően az állami szektor és a magánszektor összekacsolódásának nagyon sok formája alakult ki, amit a nagyvárosok kormányzati rendszereivel foglalkozó irodalom a „government"-től a „governance” irányába történő elmozdulásként konceptualizált. Ez lényegében azt jelenti, hogy a kormányzást (amikor az állam és a magánszektor közötti feladatok világosan kettéválnak) egy olyan rendszer váltja fel, amelyet inkább az együttmüködés jellemez (Stoker 1998).

Az elemzők két fontos ponton találják az új kormányzati együttmúködést kritikusnak. Az egyik felvetés szerint a magánszektorral való szorosabb kooperáció tulajdonképpen az állami feladatok magánérdeknek való kiszolgáltatását jelenti. A másik felvetés szerint az állami feladatok kihelyezése kvázi állami intézményekbe részben a közfeladatok kivonását jelenti a politikai szereplők kontrollja alól, részben pedig átláthatatlan kormányzati kötelezettségvállalást (Moe-Kosar 2005).

\section{Nagyvárosok a magyar önkormányzati rendszerben}

A magyar önkormányzati rendszer alapjait az 1990-es önkormányzati törvény rakta le, amely a térség egyik legdecentralizáltabb rendszerét hozta létre. A magyar rendszer az önkormányzatoknak széles körü jogokat adott a vagyongazdálkodásban, hitelfelvételekben és a szolgáltatások megszervezésének intézményi formáiban. Ugyanakkor az önkormányzatok finanszírozása alapvetően a központi szabályzók (támogatások és átengedett adók) függvénye maradt, a fejlesztési lehetőségek pedig az önkormányzatok általános pénzügyi helyzetén túl a központi minisztériumok által meghatározott ágazati programok (közlekedés, felsőfokú oktatás létesítése, fejlesztése, turisztikai beruházások, multinacionális vállalatok letelepítése) függvénye. A lakosságtól származó helyi bevételek iránti érdekeltség csekély, mivel a helyi lakossági adók, terhek emelésének politikai költségeit a várható bevételnövekedésból származó gazdasági és politikai előnyők nem kompenzálják. Következésképpen az önkormányzatok gazdasági és politikai törekvései elsősorban a támogatások maximalizálására irányulnak, ami jelentős mértékben akadályozza a politikai elszámoltathatóság érvényesülését (Hegedüs 2003; Koppányi et al 2004).

A helyi szolgáltatások színvonalát és a helyi gazdaság fejlődését a különböző típusú önkormányzatok (Budapest, megyei városok, városok, községek) alapvetően két módon befolyásolják: egyrészt maximalizálják a központi forrásokhoz (önkormányzati 
és ágazati) való hozzáférést, másrészt a piaci szereplőkkel építenek ki hatékony kooperációt a fejlesztési lehetőségek kihasználásáért.

A települések közötti verseny tehát politikai és gazdasági területen egyaránt folyik, melyben a nagyvárosok speciális helyet foglalnak $\mathrm{el}^{3}$. Az írás hátralevő részében három kérdésben elemezzük a nagyvárosok szerepét: az önkormányzati forrás szabályozása, a regionális feladatok ellátása és a nagyvárosok belső szerkezete témakörben.

\section{Kormány és a nagyvárosok harca: a forrásmegosztás újraszabályozása}

A magyar települések fejlódésének alapvetö ellentmondása (viszonylagos széles potenciális mozgástér és az azt behatároló pénzügyi korlátok) településtípusonként más és más módon jelentkezett. Bár az önkormányzati törvény lényegében nem tesz különbséget településtípusok között, a nagyvárosok (és Budapest) speciális helyzete magyarázza az önkormányzati gazdálkodás pénzügyi szabályzásának alapvető változásait az elmúlt 17 évben. A probléma lényege, hogy a nagyvárosok az 1990-es évek elején kialakított forrás- és vagyonmegosztás alapján aránytalanul nagy részesedéshez jutottak volna, ami - ha a központi kormányzat nem szól bele felborította volna az önkormányzati rendszeren belüli belső arányokat.

Az SZJA megosztás változása, a feladatellátáshoz kapcsolodó támogatások adóerőképességi mutatótól való függővé tétele, az iparüzési adó megszüntetésére és módosítására vonatkozó központi törekvések mögött az alapvetỏ cél Budapest és a nagyvárosok pénzügyi előnyeinek mérséklése volt. A központi kormányzat gyorsan szembesült azzal a ténnyel, hogy az SZJA és az iparüzési adó (valamint a fejlesztési lehetőségek által meghatározott, a központi kormányzat ellenörzésén kívül lévö vagyon értéke) a gazdasági növekedésnél sokkal gyorsabban növekszik a városi önkormányzatok esetében, következésképpen a városokat a bevétel oldalon állandó nyomás alatt kell tartani. A megoldás a megosztott SZJA szabályainak a változása, valamint az adóerőképességi mutató bevezetése volt. Az elóbbi következtében az SZJA helyben maradó aránya 50\%-ról (1992) 8\%-ra (2007) csökkent, az utóbbi segítségével pedig a jó „adóeröképességgel” rendelkezö önkormányzatokat sikerült kizárni a támogatások egy részéből. Az önkormányzati szabályozásnak ez azon kevés területei közé tartozik, melyben a különböző kormányok azonos álláspontot foglaitak el.

Amíg a nagyvárosok önkormányzati finanszírozási rendszeren belüli helyzetét egyfajta konfliktus jellemzi, addig az ágazati programokon belüli prioritásaik megkérdőjelezhetetlenek. Az infrastrukturális programok hatékonyságának egyik fontos tényezöje a népességszám, így szinte valamennyi területen egyszerü hatékonysági kalkuláció alapján a nagyvárosok előnyöket élveznek. Például a vasúti korszerüsítés (intercity), szennyvizprogram ${ }^{4}$, autópályák, bérlakásépítési program, lakótelep felújitási program, ipari parkok stb. Az ágazati programok településtípusok közötti megosztása nagyobb egyenlötlenségeket eredményez, mint a finanszírozási rendszer általános elemei, aminek nemcsak politikai magyarázata van, hanem gazdasági is. 
A nagyvárosi kormányzatok ...

A nagyobb ellátó rendszerek (szennyvíztisztítók, hulladékártalmatlanítók stb.) kiépitésének beruházási költségei fajlagosan alacsonyabbak, a beruházás megtérülése gyorsabb a nagyobb települések esetében, ami jelentös komparatív előnyt jelent. A 2000 és 2004 közötti bérlakásprogramban felhasznált támogatás (kb. 50 milliárd Ft) 36\%-a megyei jogú városokba került, a 2004 és 2006 közötti panelprogram támogatásainak (kb. 30 milliárd $\mathrm{Ft}$ ) pedig 72\%-a. A 2008-ban induló EU Strukturális Alapok városrehabilitációt támogató programjaiban a megyei jogú városok külön keretet kaptak, amiben nem kell osztozniuk más városokkal.

A nagyvárosok pénzügyi helyzetét azonban költségvetési bevételeken és kiadásokon kívül más tényezök is befolyásolják. Az önkormányzatok szolgáltatásaik egyre nagyobb hányadát szervezik meg a költségvetésen kívüli szervezeti formákban. A rendszerváltást követő másfél évtizedben az önkormányzatok (a költségvetés kiadásain keresztül mért) részesedése a GDP-ből meglehetősen stabil maradt a 12,5-14,5\%-os sávban. A költségvetésen kívül nyújtott szolgáltatások nagyságát 2000-ben a GDP 2,6\%-ára, 2005-ben a GDP 3\%-ára becsülhetjük (Hegedüs-Tönkö 2007b) ${ }^{5}$. Ez a kvázi önkormányzati szektor elsősorban a városokban, ezen belül is a nagyvárosokban található meg, ahol koncentrálódik az önkormányzati hitelezés, a közösségi szféra és a magánszféra kooperációjára épülő programok, és az önkormányzati tulajdonú és az önkormányzati alapítású kht-k, gazdasági társaságok is.

Az önkormányzatok állandó (közfeladatok nagysága és a rendelkezésre álló források különbsége által meghatározott) pénzügyi nyomás alatt vannak. A nagyvárosok mozgástere sokkal szélesebb, mint a kisebb településeké, amelyek a vagyoni és gazdasági lehetőségek hiányában szinte kizárólag a központi támogatásoktól (pl. „önhiki”) függnek. A nagyvárosok helyzete azonban nagyon különböző, melyet a helyi szolgáltatásokat és gazdálkodást jellemzỏ indikátorok eltérései jól mutatnak (hitelek aránya, szolgáltatási díjak nagysága, az önkormányzati bevételek szerkezete stb.) Ezek a különbségek számos tényezöre vezethetők vissza, mint pl. az önkormányzati vagyon, a fejlettségbeli korábbi különbségek továbbélése, az eltérö piaci pozíció és az önkormányzat eredményessége a központi programok megszerzésében. A gyenge piaci pozíció, az örökölt hátrány és a gazdasági szerkezetváltozás nagyvárosokat is szisztematikus hátrányos helyzetbe hozhat, amiböl csak specifikus programokkal lehet kiemelkedni. Ilyen pl. Salgótarján helyzete, amely tipikusan a „gyenge piaci helyzetư" városok jellemzőivel rendelkezik.

A magyar önkormányzati rendszer egyik (elsősorban nagyvárosokat fenyegető) veszélye, hogy a pénzügyi nyomás alatt a strukturális átalakítások helyett (szolgáltatások átalakítása, bevételek növelése stb.) „megalkuvó” szervezeti-pénzügyi megoldások válhatnak uralkodóvá: különböző mértékủ és formájú, időben eltolt, közvetetten jelentkező kötelezettségvállalások (hitelek felvétele, vagyon felélés, kötvénykibocsátás, magántársaságok felé vállalt, költségvetésben nem jelentkező kötelezettségek stb.). Egy elemző tanulmányban rámutattunk, hogy a feltételes kötelezettségvállalás lehetöségeivel elsősorban a nagyobb városok (Budapest és a megyei jogú városok) élhetnek, melynek oka többek között a városok mérete, az önkormányzati vagyon nagysága, a közszolgáltatások szélesebb köre és a helyi lakosság fizetőképessége 
(Hegedüs-Tönkő 2007a). Az önkormányzatok előnyben részesítik azokat a szervezeti megoldásokat, amelyek költségeit végső soron az állam fizeti. Ez magyarázza az adók optimalizálását célzó önkormányzati holdingok népszerüségét.

Nehezen ítélhetö meg, hogy a nagyvárosok mennyire vannak túl- vagy alulfinanszírozva, hiszen ehhez minimum ismerni kellene a különböző települések kiadásszükségletét. Mindenesetre az önkormányzati politikusok (sokszor és jól dokumentált) pénzügyi nehézségeik esetén sem nyúltak a helyi adóterhek növelésének eszközéhez, ami egyébként egy valódi önállósággal rendelkezö önkormányzat esetében meg kell, hogy elözze az állami beavatkozást (támogatások növelése).

\section{Nagyvárosok és a térségi funkciók}

Az 1990-es törvény a megyék gyengitése érdekében kivette a nagyvárosokat a megyék alól. A „lyukas” megyék számos konfliktus forrásai, ahol a korlátozott önkormányzati jogokkal rendelkezö megyei önkormányzat és a megyei jogú városok kompetenciái (feladatmegosztás) és érdekei ütköznek. Ugyanakkor azt is látni kell, hogy a városi vonzáskörzetek nem határolhatók egyértelmüen el, mivel egyrészt az egyes szolgáltatási szektorokban más és más a vonzáskörzet (pl. a vízügy és az oktatás esetében), másrészt pedig a vonzásterület időben változhat. Következésképpen illúzió azt gondolni, hogy ezek a konfliktusok egyszerüen felszámolhatók.

A magyar önkormányzati rendszerben a megyék és megyei jogú városok közötti konfliktusokban a történelmi és politikai vonatkozásokon túl a különböző testületek közötti rivalizációnak is szerepe van. Az önkormányzati finanszírozási rendszer (a vagyonátadás és támogatási rendszerbe épített ösztönzők) ellentmondásai alapvetöen befolyásolhatják a megoldásokat. Nem véletlen, hogy a megyei jogú városok sorra adták át a megyének „veszteséget termelö" intézményeik egy részét, bár ezt nehéz szivvel tették, hiszen ezáltal a hatalom, a befolyásolás egy részéröl is lemondtak. A megyei rendszer leépítése, a kistérségek és régiók erősítése racionálisabbá tehetné a térségi funkciók ellátását, de - ha kisebb mértékben is - azért fennmaradnának területi átfedések az ellátási területek között.

Az 1990-es önkormányzati reform nem minden elemében vette át a 1980-as években kikísérletezett megoldásokat, így az 1984-ben elkezdett városkörnyéki rendszer sértette a települési önállóság elvét, és nem is került be az új törvénybe. A nagyvárosok és a városkörnyék konfliktusai a közszolgáltatások és területfejlesztés területén explicitté váltak. Illúzió, hogy ezeket a konfliktusokat automatikusan fel lehet számolni a nagyobb önkormányzatok kialakításával - azok továbbra is fennmaradnak, csak önkormányzaton belüli konfliktusokká válnak (lásd a részönkormányzatokról késöbb).

A kistérségek lettek hivatottak arra, hogy a város és környéke közötti kooperációt és konfliktusokat kezeljék. A kistérségekben a nagyvárosok politikailag és gazdaságilag is domináns szerepet játszanak, de nehezen dönthető el, hogy a környéki kistelepülések jobban vagy rosszabbul járnak a kooperáció esetén. Az oktatás területén a nagyvárosok például többnyire a saját bevételükből fedezik a normativa 
és a tényleges költségek közötti különbségeket a városon kivüllröl bejáró tanulók esetében. Továbbá számos olyan szolgáltatást fenntartanak, amelyek hatása túlmutat a városi település határain. Például az önkormányzatok által támogatott helyi TV-k tipikus esetben elérik a környék lakosságát is. ( $\mathrm{Pl}$. Zalaegerszegen a városi TV adásai elérik a $27 \mathrm{~km}$ sugarú régió 55 településének lakóit.) De a víz- és csatornaszolgáltatás esetében a csatornázatlan területen élő nem városi lakosok azok, akik a tipikus keresztfinanszírozás miatt (a vízdíjakat a valódi költségek felett, a csatornadíjakat a tényleges költségek alatt állapítják meg) hozzájárulnak a városi lakosok csatornadíjaihoz. Mindenesetre a kooperációra való pénzügyi ösztönzésre a települések rugalmasan reagálnak. A tapasztalat az, hogy a kooperáció gyakran formális, addig terjed, ami még a többlettámogatás lehívását lehetővé teszi, de ez mindig magában hordozza a későbbi valódi kooperáció lehetóségét.

A kormányzat (és a pártok egy részének) azon törekvése, hogy a kistérségeket erősítsék, nem feltételenül egyezik a nagyvárosok érdekeivel. A kérdés az, hogy milyen szerepük van a nagyvárosoknak a kistérségekben, el tudják-e érni azt, hogy politikai erejük a népességnagysággal arányos legyen (Bércesi 2003).

A megyei jogú városokat azonban sokkal jobban megosztja a „fejlesztési pólusok" koncepció, amely az öt nagyvárost (Budapestet, Debrecent, Győrt, Miskolcot, Pécset és Szegedet), mint nemzetközi jelentóségü fejlesztési pólusokat határozza meg. A Közép-dunántúli régióban a fejlesztési pólus funkció megoszlik Székesfehérvár és Veszprém között. A programoknak elvileg biztosítaniuk kell a pólusok és a nagyobb térségükbe tartozó nagyvárosok hálózatos együttmüködését, de senkinek sincs kétsége a felól, hogy a pólusprogram az erőforrások koncentrációját, a kiemelt települések fokozottabb támogatását jelenti. Nem véletlen tehát, hogy más térségekben is felmerül az egy-pontú pólus helyett a fejlesztési „tengely” koncepciója, ami egyfajta visszatérést jelent a megyei székhelyek általában vett kiegyenlített fejlesztéséhez. A nyugat-dunántúli városok például a Nagykanizsa-SopronSzombathely-Zalaegerszeg tengelyt javasolják. A pólus program a területfejlesztés egyik legvitatottabb kérdésébe nyúl bele, vajon az állami beavatkozás célja a területi egyenlőtlenségek mérséklése vagy a gazdasági fejlődés elősegitése? Az európai országokban is az a tapasztalat, hogy a retorika és a tények gyakran mást mutatnak, a nemzetállamok amíg a politikai dokumentumokban a kiegyenlített fejlödést támogatják, tényleges programjaikban a kiemelt városi térségeiket akarják nemzetközi versenyhelyzetbe hozni.

A megyei városok látszólagos egysége több területen is megtörni látszik. A közigazgatási rendszer továbbfejlesztésének sarkalatos pontja az önkormányzati régiók létrehozása, amely szükségképpen érdekellentétet teremt a megyei központok között. Az alapkérdés az, hogy centralizált vagy policentrikus régiók lesznek-e? 


\section{A nagyvárosok belső struktúrája, a részönkormányzatok}

A mai magyar önkormányzati rendszer egyik legfontosabb és talán leggyakrabban is felidézett kritikus pontja a széttagoltság. Ugyanakkor a városi települések esetében pontosan ennek az érvnek az ellenkezöje jelenik meg, mégpedig az, hogy az önkormányzatok túlságosan nagy, heterogén társadalmi összetételü csoportokat képviselnek, ahol a specifikus problémák és érdekek nem tudnak megielenni. Ez a probléma különösen a nagyvárosok esetében jelenik meg, amelyek több település összeolvadásából jöttek létre, vagy amelyek területén jelentős külterületi népesség él, vagy ahol a lakóterülettől elkülönülő, de az önkormányzat területéhez tartozó üdülőterület létezik. A helyi önkormányzatokról szóló törvény megteremtette a lehetőségét annak, hogy az önkormányzatok saját területükön belül létrehozhassanak részönkormányzatokat. A képviselötestület saját hatáskörön belül dönthet a részönkormányzat felállításáról, amely önkormányzati képviselökböl és más választópolgárokból állhat. A részönkormányzati testület tagjait az önkormányzati képviselőtestület választja meg, vagy dönt a megválasztásuk módjáról. Az egyetlen megkötés, hogy a vezetője csak képviselő lehet. Lakossági kezdeményezés esetén kötelező a részönkormányzat létrehozása: 1) az egyesítéssel létrejött településrészen; 2) külterületi lakott helyen; vagy 3) olyan üdülőterületen, amelynek népessége eléri a település állandó lakosságának egynegyedét. A képviselötestület dönthet a részönkormányzat megszüntetéséről is, ha a müködés feltételei nem biztosíthatók.

2006-ban 152 településrészi önkormányzat müködött Magyarországon ( $B M$ 2006). „A legnagyobb létrehozott részönkormányzat lakosságszáma 23205 fö (Budapest IV. kerületében), a legkisebbé 22 fố (Vérteskozma településen). A részönkormányzatok 47\%-a korábban egyesített településrészen jött létre, $29 \%$ elkülönült településrészen. Alacsonyabb arányban jöttek létre külterületi lakott helyen (14\%) és üdülőterületen $(6 \%)$. Az országban összesen 4 lakótelepen müködő részönkormányzat található ... az átlagos testületi létszám $4-6$ fö (a legkisebb 2 fövel, a legnagyobb 25 fövel múködik)." ( $B M$ 2006, 5) A településrészi önkormányzatok nagyon különböző anyagi lehetőségekkel rendelkeznek: 2005-ben 21 részönkormányzat rendelkezett 5 millió Ft feletti összeggel.

A múködö részönkormányzatok egy újabb lépést jelentenek a decentralizáció irányába. Nagyobb településeken belül a részönkormányzat bevezetésének célja az, hogy biztosítsa a település egységét (az egész településre vonatkozó szolgáltatások hatékonyságát), ugyanakkor teret adjon a helyi kezdeményezéseknek is. Általában két veszély jelentkezik a részönkormányzatokkal kapcsolatban. Egyrészt a részönkormányzat csupán egy „lépés” a településrész önállósodása felé, mint pl. Sátoraljaújhely esetében, ahol Széphalom leszakadása érdekében már háromszor szerveztek népszavazást. A másik veszély az, amikor a részönkormányzat felállítását egy politikai párt területi terjeszkedése motiválja és nem a helyi képviselet és önkormányzatiság megjelenése. 


\section{Következtetések}

A globalizációs folyamatok, a decentralizáció és regionalizáció keretei között a nagyvárosi kormányzatok helye is változik. A nemzetközi trendek a nagyvárosi kormányzatok jelentőségének növekedését igazolják, annak ellenére, hogy a nagyvárosi régiók politikai és gazdasági önállósodási törekvéseit a nemzetállamok, régiók és a nagyvárosi szint alatti önkormányzatok többé-kevésbé sikerrel fékezik. A tanulmány elsỏ részében a nemzetközi irodalom rövid áttekintése után arra a következtetésre jutottunk, hogy a nagyvárosi kormányzatok helyzetét két összefüggésben lehet megragadni: egyrészt az önkormányzati rendszeren, másrészt pedig az állam és a magánszektor kapcsolatrendszerén keresztül. A dolgozat második felében a magyar önkormányzati rendszeren belül vizsgáltuk a nagyvárosok (lényegében a megyei jogú városok) helyzetét.

A tanulmány egyik fontos következtetése, hogy a nagyvárosok a magyar önkormányzati rendszeren belül egyfajta érdekcsoportot jelentenek. A gazdaságitérbeli szerveződési folyamatok középpontjában egyre inkább a megyei jogú városok és az ezen a szinten kialakult területi koalíciók állnak, amelyek meghatározó politikai szerepet játszanak a területi-közigazgatási rendszer továbbfejlesztésében, az ágazati reformok politikai elfogadtatásában és gyakorlati alkalmazásában. Ez lényegében két dolgot is jelent: részben a megyei jogú városok meghatározó politikai súllyal rendelkeznek a megyei szintü újraelosztásban, régiós folyamatokban és a központi költségvetési politikában, másrészt pedig a meghatározó gazdasági szereplök (külföldi tőke, bankok, ingatlanfejlesztők stb.) stratégiája egyre inkább támaszkodik a megyei városok politikai és gazdasági elitjeivel való koalícióra.

A magyar politikai rendszerben az önkormányzati képviselöknek jelentős és sokak által vitatott szerepe van, amit jól jelez a politikai összeférhetetlenség felvetése a képviselöi és polgármesteri funkciók körül. Egy néhány éve publikált tanulmány szerzői (Dénes-Marelyn Kiss 2004) úgy látták, hogy a pártok benyomultak az önkormányzatokba. Mi inkább úgy érvelnénk, hogy az önkormányzatok, köztük a megyei jogú városok nyomultak be a politikába, és játszanak szerepet nemcsak a központi források elosztásában, hanem a szabályrendszer kialakításában is.

A nagyvárosok ugyanakkor nemcsak politikai, hanem fontos gazdasági hatalommal is rendelkeznek. Adottságaik folytán a gazdasági fejlődés „növekedési pólusait” képviselik, anélkül, hogy erre vonatkozóan kormányrendeletek születnének, és ez a tény, még politikai képviselet nélkül is, kiemelt pozíciót biztosít a nagyvárosoknak. Nem véletlen, hogy a stabil helyzetben lévő polgármesterek, ha választaniuk kellene, inkább a polgármesteri, mint a parlamenti képviselöi pozíciót választanák. A nagyvárosok közös jellemzői mögött azonban jelentős különbségek vannak, amelyeket az adottságokon kívül (gazdasági és politikai befolyás) a helyi politikai elit felkészültsége és kompromisszumkészsége is befolyásol. 
Tisztában vagyunk azzal, hogy ezek a megállapítások sok szempontból hipotetikus jellegúek, de úgy véljük, termékeny eszközt nyújtanak arra, hogy strukturálják és egyben új összefüggésbe rendezzék ismereteinket.

\section{Jegyzetek}

1

1 Köszönettel tartozok Tönkő Andreának a tanulmányhoz füzött megjegyzéseiért.

${ }^{2}$ Lásd pl. az Ágh Attila által vezetett IDEA munkacsoport anyagait (http://www.idea.gov.hu).

${ }^{3}$ Budapest a maga 23 önkormányzatával speciális problémát jelent, amelyet ebben az írásban nem tárgyalunk. Érdemes megjegyezni, hogy bár a kerületek jelentős politikai önállósággal rendelkeznek, de a sokat kritizált forrásmegosztás a bevételek radikális újraelosztását jelenti, amit a megfigyelök gyakran figyelmen kívỉl hagynak. A politikailag fragmentált (kormányzatilag elkülönült), de összeépült nagyvárosokban a helyzet még ennél is rosszabb, mivel ezeket a városokat nemcsak a megosztottság, hanem a rendkívil nagy jövedelemegyenlötlenség is jellemzi.

${ }^{4}$ A megyei városok számára speciális szennyvízprogram indult a kilencvenes évek közepén.

${ }^{5}$ A becslést részben a tíz legfontosabb szolgáltatási területen az 50\%-ot meghaladó önkormányzati tulajdonban lévő vállalatok árbevétele alapján, illetve a nonprofit szektoron belül a kht-ék önkormányzati támogatással csökkentett árbevétele alapján becsültük. Ez egy "alsó közelítésnek" tekinthetö, hiszen az önkormányzatok rendelkeznek számos olyan gazdasági társasággal, amelyek nem a kiválasztott szolgáltatási területen müködnek. (Pl. helyi TV-t, rádiót, mozikat üzemeltető gazdasági társaságok, vagy helyi újságot kiadó cégek, vagy hogy egy nagyobb árbevételü területet említsünk, uszodák, gyógyfürdők, sportpályák).

\section{Irodalom}

Arnott, R.J. (1979) „Optimal City Size in a Spatial Economy.” - Joumal of Urban Economics, 6. 65-89. o.

Atkinson, R. (2004) Creating the city region in the UK: the challenge of neighborhoods. Paper presented at a Regional Studies Association conference CITY REGIONS: Creating new urban futures? October 18 th. London.

Barlow, I.M. (1997) Administrative systems and metropolitan regions. - Environment and Planning C: Government and Policy. 15. 399-411. o.

Barlow, I.M. (2000) Amsterdam and the question of metropolitan government. - Heinemeijer en Dick, van der V. (ed.) Understanding Amsterdam: Essays on economic vitality, city life and urban form. Het Spinhuis, Amsterdam.

Bércesi F. (2003) A nagyvárosok helye, szerepe és funkciója, valamint a környezetével való kapcsolata (a kistérségek szemszögéböl). IDEA munkacsoport. Kézirat.

Bird, R.M.-Slack, E. (2004) Fiscal Aspects of Metropolitan Governance. International Tax Program, Rotman School of Management, University of Toronto and Enid Slack Consulting Inc., Toronto. Manuscript.

Bish, R.L.-Ostrom, V. (1973) Understanding Urban Government: Metropolitan Reform Reconsidered. American Enterprise Institute.

BM (2006) Tájékoztató a lakótelepi részönkormányzatok mủködéséhez nyújtott segitségrōl, valamint a lakótelepi részönkormányzatok részére kiirt pályázat tapasztalatairól. Belügyminisztérium, Budapest.

Box, R.C.-Musso, J.A.M. (2004) Experiments with Local Federalism Secession and the Neighborhood Council Movement in Los Angeles. - The American Review of Public Administration. 3. 259-276. 0.

Dénes A.-Marelyin Kiss J. (2004) Azért a politika az úr (Az önkormányzati multipozicionális elit kialakulása Magyarországon). - WEB. 12. 25-40. o.

Gulick, L.M. (1957) Changing problems and Lines of Attack. Washington.

Hegedüs, J. (2003) Decentralisation and structural adjustment in Hungary. - Brillantes, A.-Ilago, E.S.Santiago, B. (eds.) Decentralisation and Power Shift. Esden. 461-495. o.

Hegedüs J.-Tönkö A. (2007a) „Az őnkormányzati gazdasági társaságok szerepe a helyi önkormányzatok vagyongazdálkodásában." - Vigvári A. (szerk.) A családi ezüst. Tanulmányok az önkormányzati vagyongazdálkodás témaköréből. KszK ROP 3.1.1. Programigazgatóság, Budapest. 67-94. o. 
Hegedüs J.-Tönkő A. (2007b) Önkormányzatok költségvetésen kivìli intézményeinek vizsgálata. Városkutatás Kft., Budapest. Kézirat.

Jones, V. (1942) Metropolitan Government. University of Chicago Press, Chicago.

Kamal-Chaoui, L. (2004) OECD Metropolitan Regions: What role for the central governments? OECD.

Koppányi, D.-Wetzel, S.-Daher, E. (eds.) (2004) Intergovernmental Finance in Hungary: A Decade of Experience 1990-2000. World Bank Institution.

Lefevre, Ch. (2001) Metropolitan Government reform in Europe (2001): Trends and challenges. - Revue Suisse de Sciences Politiques. 3. 136-141, o.

Lowndes, V.-Sullivan, H. (2006) 'How low can you go? Rationales and challenges for neighbourhood governance'. - Public Administration. Manuscript.

Markusen, A.R. et al. (1999) Second Tier Cities: Rapid Growth Beyond the Metropolis. University of Minnesota Press, Minneapolis.

Moe, R.C.-Kosar, K.R (2005) The Quasi Government: Hybrid Organizations with Both Government and Private Sector Legal Characteristics. Updated May 18, 2005 CRS CRS Report for Congress Received through the CRS Web.

Ostrom, Vi.- Tiebout, Ch.-Warren, R. (1961) The Organization of Government in Metropolitan Areas: A Theoretical Inquiry. - American Political Science Review, 4. 831-842. o.

Singell, L.D. (1974) Optimum City Size: Some Thoughts on Theory and Policy. - Land Economics. 3. 207-212. o.

Stoker, G. (1998) „Governance as Theory: Five Propositions.” - International Social Science Journal. 155. 17-28. 0 .

Szirmai V. (2004) Globalizáció és a nagyvárosi tér társadalmi szerkezete. - Szociológiai Szemle. 4. 3 -24. o.

Vogel, R.K. (2005) Governing Large Cities: A Comparative Perspective: Presentation at the Munck Centre for International Studies. University of Toronto, University of Louisville, October 19. Toronto.

\section{GOVERNMENTS OF THE CITIES AND SYSTEM OF THE LOCAL GOVERNMENT}

\section{JÓZSEF HEGEDÜS}

The paper first gives an overview of the literature on metropolitan government in developed countries, and in the second part focuses on the urban governments of the cities with county rights ("large cities") in Hungary. The main conclusion of the paper is that large cities have a decisive role in the regional system of Hungary. The major changes of the intergovernmental fiscal relations in the last 15 years have been influenced by the conflict between the central government and large cities (and Budapest) because of the relatively good position of latter. The large cities have been the main beneficiaries of the sectoral development programs (water, housing, transportation, etc.), and serve as 'natural growth poles' of regional development. The political lobbying of large cities was strong enough not only to roll back the county municipalities an to deactivate the regional reforms proposals. 